\title{
Practices of Fruit Growing. Applying ontology to taste in Penang and beyond
}

Leo Mariani

\section{(2) OpenEdition \\ Journals}

Electronic version

URL: http://journals.openedition.org/ethnoecologie/3869

DOI: 10.4000/ethnoecologie.3869

ISSN: 2267-2419

\section{Publisher}

Laboratoire Eco-anthropologie et Ethnobiologie

\section{Electronic reference}

Leo Mariani, "Practices of Fruit Growing. Applying ontology to taste in Penang and beyond", Revue d'ethnoécologie [Online], 14 | 2018, Online since 31 December 2018, connection on 24 March 2021. URL: http://journals.openedition.org/ethnoecologie/3869; DOI: https://doi.org/10.4000/ethnoecologie. 3869

This text was automatically generated on 24 March 2021.

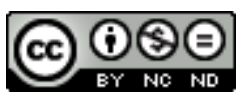

Revue d'ethnoécologie est mis à disposition selon les termes de la licence Creative Commons Attribution - Pas d'Utilisation Commerciale - Pas de Modification 4.0 International. 


\title{
Practices of Fruit Growing. Applying ontology to taste in Penang and beyond
}

\author{
Leo Mariani
}

One question remains unanswerable for me: What if the other living creatures were the ones who taught humans? What if the horses taught them how to run? The frogs how to swim? The plants

how to wait?

A.-G. Haudricourt (Haudricourt \& Dibie 1987:169)

1 Intuitively, we define taste as the subjective representation of a sapid sensation. Recent literature has shown however that this is only part of the picture, and thus the study of taste perception and how humans relate to food remains a field open for exploration (Mintz 1996; Hennion 2007; Van de Port \& Mol 2015). In this article, a particular emphasis will be given to the fact that, throughout Asia, taste can be associated to the absence of flavor: an appetite for "blandness" (Jullien 2004) in some cases, or, as I will show, an attraction for the numb taste. Both are insipid and question intuitive categories. They also provide a window into a little known aspect of the senses, where taste perception is played out in the realm of the virtual, in the taster's openness to a set of potential rather than actual possibilities (Jullien 2004), and in the ability of food to support and suggest these potentialities.

2 As opposed to blandness, the numb taste elicits a reaction from the taste buds: it renders the tongue and the inside of the mouth numb. My discussion of this rare sensation is enabled by a Southeast Asian fruit, the durian. According to Shingo Hamada, a Japanese colleague of mine, aficionados of the fugu pufferfish, the deadly venomous fish which makes up the object of a veritable culinary cult in Japan, also mention the numb taste, which is perceptible when the fish is consumed very fresh. Aside from particular durians, my only other experience of the numb taste was occasioned by Xanthoxylum piperitum, a small berry commonly known as "Sichuan 
pepper," in reference to the Chinese region where it is traditionally grown. From the extensive research done on Sichuan pepper, we know that in that case the numbing sensation is induced by a chemical molecule: sanshool (hidroxy-a-sanshool). However, contrary to what the use of the term "pepper" might suggest, a distinction must be made between the effects of sanshool and those of most peppercorns. Like chili peppers, the latter contain capsaicin, an irritant that works by activating heat receptors in the mucous membranes of the mouth and tongue. In short, it burns. Sanshool, on the other hand, has a paresthesic effect: it triggers a mechanical malfunctioning of the tactile sense by literally making specific receptors in the mouth and tongue vibrate on a frequency that the brain cannot process (Hagura et al. 2013). From a tactile point of view, since this is what it is all about, the numb taste feels like a slight tingling sensation, with a slightly anesthetic effect on the mucous membranes of the mouth. The sensation can last several minutes, blurring perception of other flavors. For those unaccustomed to it, it is often neither particularly pleasurable, nor disagreeable, but rather amusing or awkward.

Figure 1: Two durians cut open (one with yellow flesh, the other with white flesh)

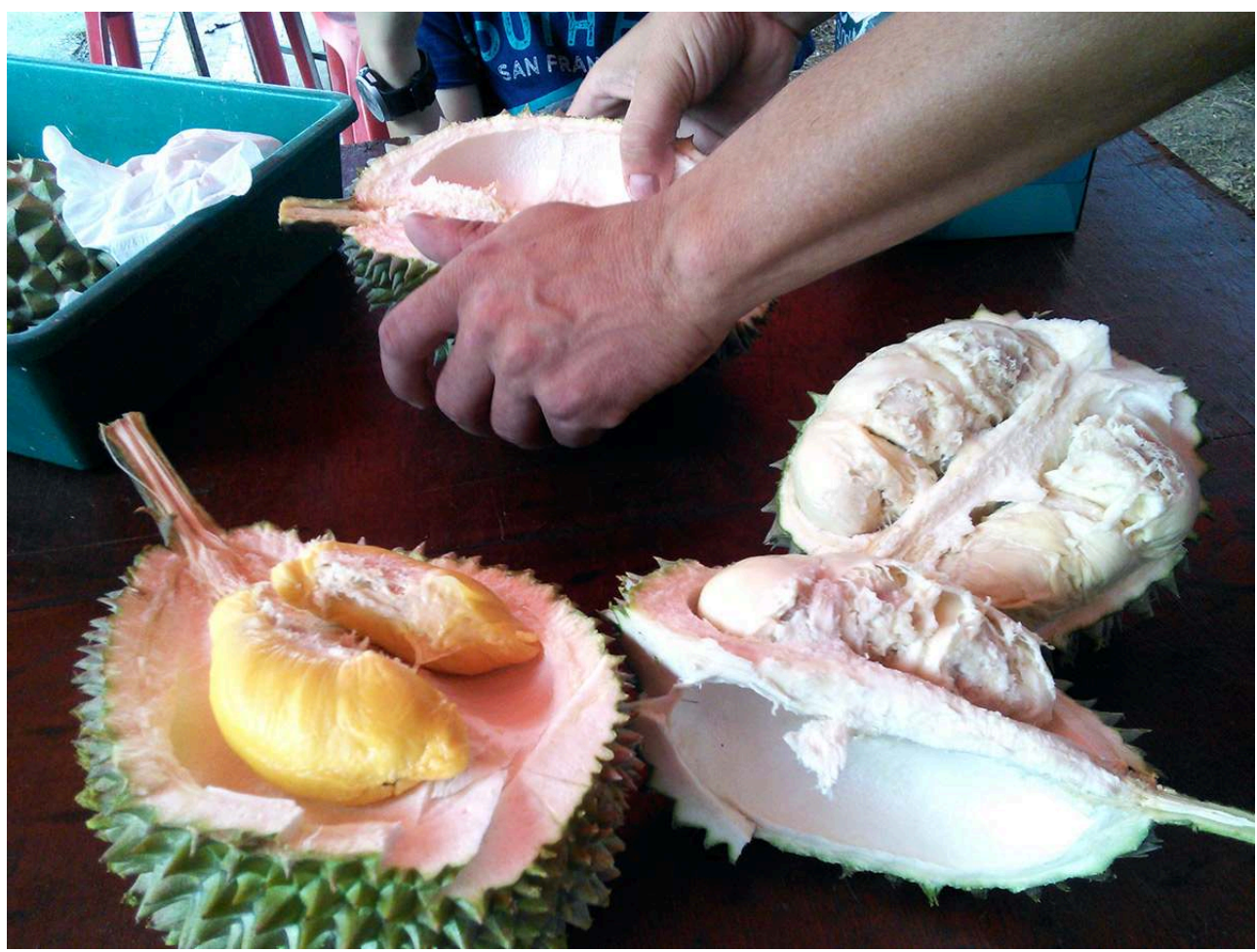

IN THE BACKgROUND, THE HANDS ARE BUSY SPLITTINg THE HULL IN TWO TO gET TO THE FLESH INSIDE (c) L. MARIANI - PENANg (GEORgETOWN), 2018

3 Durians can trigger the numb taste under particular circumstances, especially related to freshness. On the plantations of Malaysia, ${ }^{1}$ it is relatively simple to experience this tingling numbness. For reasons to be discussed later, this is more difficult in Singapore, at the southern tip of the Malay Peninsula, where many of the best durians are exported. There I met aficionados who approached the numb taste with awe, as an experience that one must have at least once in a lifetime. For some, it is thus a rare, singular opportunity. For most, interest remains rather low, even in a region famous for its passionate love for the durian as this one, where opportunities abound. But the 
numb taste has found its biggest advocate on Penang Island. I will call him Tim, not so much to protect his identity as not to encroach on his online reputation. Tim is a producer of durians, one of the best known in Penang, Malaysia, and the world. He owes his popularity to the quality of his fruit, as well as to his aesthete's discourse, particularly his advocacy for the numb taste-a taste which he claims "contains all the other tastes" and places at the heart of the experience he offers to his customers.

In this article, I use the numb taste as the privileged entry point into the more general question of human-food relations, in an approach encompassing different fields, namely knowledge, consumption and production. In his aesthetic theory, Luigi Pareyson (2007:21)suggested that forms, understood as the sensory manifestation of the properties of matter, should be defined "in the act of concluding, and at the same including, the movement of production that orients [them] and finds in them its own successful completion"'. Applied to the "durian forms", Pareyson's insight enables us to grasp how human worlds are lived as they are made. To establish these connections implies steering clear of any abuse of theory to focus on the interplay of relations that the ethnography of the numb taste and its context brings to light. Next, these relations must be conceptualized, their shared characteristics singled out and discussed.

5 Most origin myths known to us do not posit language or culture as what distinguishes humans from animals, positing instead the domestication of fire and its use to cook food (Lévi-Strauss 1964). Our relationship to food is therefore at the center of how we define ourselves. It is also one of the major environmental challenges for the future. If the planet's future is linked to biodiversity, it is therefore right to conclude that it depends on how humans define their humanity, more specifically on the organization of the existential relations that they establish with the world.

6 The first section will provide a description of the general background of the production and consumption of durians in Malaysia and Singapore-a little known context, defined by an agricultural constraint which is in blatant contradiction, to say the least, with the principles of modern agriculture. The second section focuses on an account of Tim's practices and his taste for the numb taste, followed by a discussion of his taste in the context of Malaysia's global production, which conceptualizes it as a specific positioning towards plants. The last section will come as a synthesis, in an endeavor to link Tim's taste engagement with the world to economic and agricultural practices and to put the case in a regional and global perspective. Finally, I will provide some reflections on the practical and sensory consequences of ontological choices. 
Figure 2: A durian stall being stocked

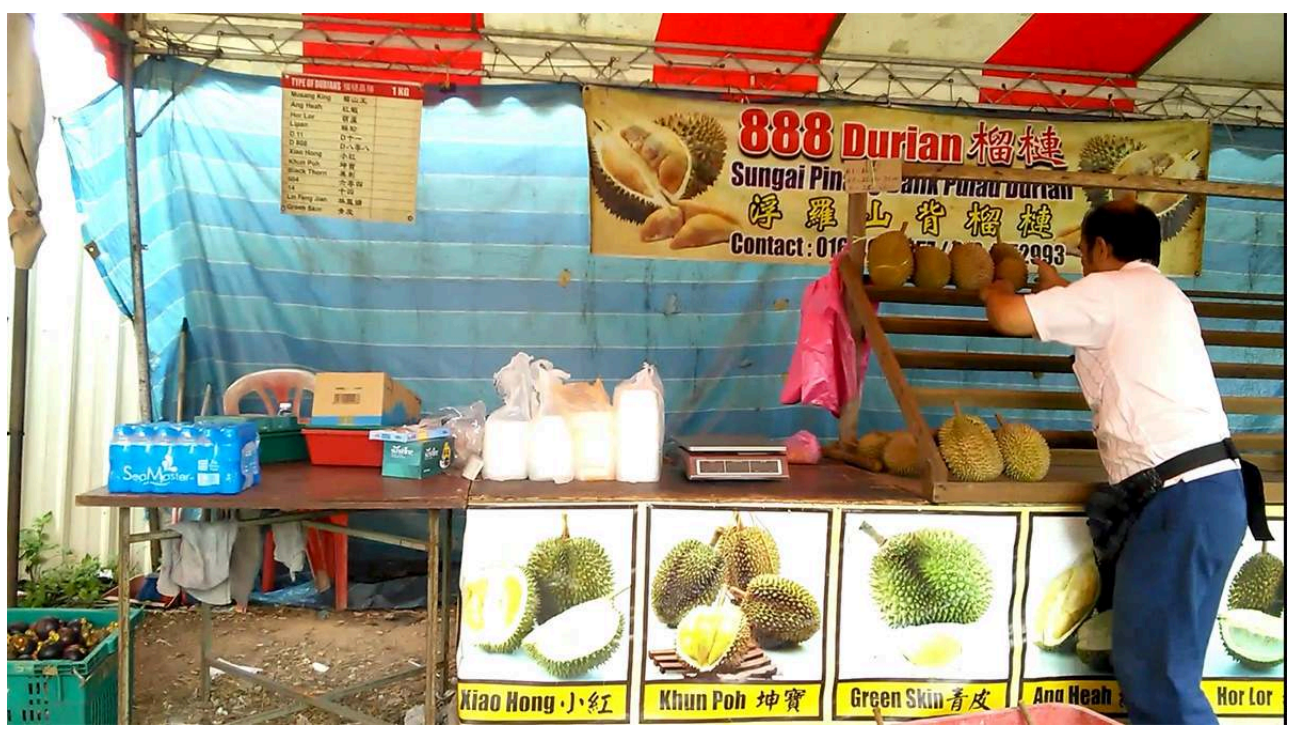

THE FRUITS ARE USUALLY SORTED ACCORDING TO VARIETY (YOU CAN SEE THE PRICE LIST IN THE RIgHT LEFT CORNER) AND EATEN AT THE BACK OF THE STALL, FROM TABLES. MANY DURIAN SELLERS (AND gROWERS) ARE CHINESE, HENCE THE IDEOgRAMS. IN THE BOTTOM LEFT CORNER, YOU CAN SEE A CASE OF MANGOSTEENS, WHICH ARE TRADITIONALLY EATEN AFTER THE DURIANS TO LOWER BODY TEMPERATURE; THE DURIAN IS CONSIDERED A VERY HOT FRUIT, ACCORDING TO BOTH CHINESE MEDICINE AND FOLK BELIEFS

(c) L. MARIANI - PENANg (GEORgETOWN), 2018

\section{About waiting and a game-changing ontological principle}

7 It might seem curious to some readers to find no mention so far of the smell of the durian. The fruit, however, has indeed a truly smelly reputation-it is said to smell of "death," "excrements" or "vomit," if we are to trust accounts in the travel literature or the rumors that roam the Internet. This emphasis on the smell is in fact the result of a specific history where colonial relations mix with definitions of the body and chemical molecules, a history that originated with Western cultures (Mariani 2015, 2017 et 2018). Notwithstanding, the smell will not be featured in the body of this article for the simple reason that it was not once mentioned during the fieldwork I draw on.

The Penang Island, located a stone's throw away from the Malaysian west coast, is a hotspot for the production of durians. People come here from all over Asia to visit the plantations which dot the island's steep western slopes where durian trees old and young, wild and domesticated grow side by side. It is indeed one of the particularities of the site to offer this wide diversity of cultigens and modes of growing this fruit. Within a small area, non-pedigree durians, or kampong durians, "village durians," whether retrieved from the forest or grown in the backyard, are cultivated alongside an impressive collection of cultivars created on professional plantations, with reputations that sometimes exceed the borders of the island or country ${ }^{3}$ (Figure 3). While throughout Malaysia durian production is becoming increasingly standardized, due to modernization and the advent of the durian as a cash crop, ${ }^{4}$ Penang remains for now a model of diversity. Durians have been grown for a very long time on this cramped island where the forest keeps encroaching on farm land and gardens, encouraging 
cross-pollination, new growth, propagation by wood cuttings and grafting, and, consequently, the appearance of new fruits. Some durians can be bought from hawkers on the side of the road for a few eurocents, while others can be a hundred times more expensive (up to twenty euro per kilogram). ${ }^{5}$ In general, the price depends on the volume of the production, and therefore on how far into the season it is, fruit varieties, caliber, freshness and origin, given that people are willing to pay a lot to taste durians from renowned growers, even from particular trees. The price can also vary from one day to another, based on the weather conditions: for instance, rain during the ripening season alters the texture of the flesh, which becomes waterlogged, and dilutes the flavors. Similarly, strong winds knock down the durians resulting in unripe fruit reaching the market and, consequently, lower prices.

Figure 3: In a Malaysian state-owned shop selling durians and other local products in Singapore

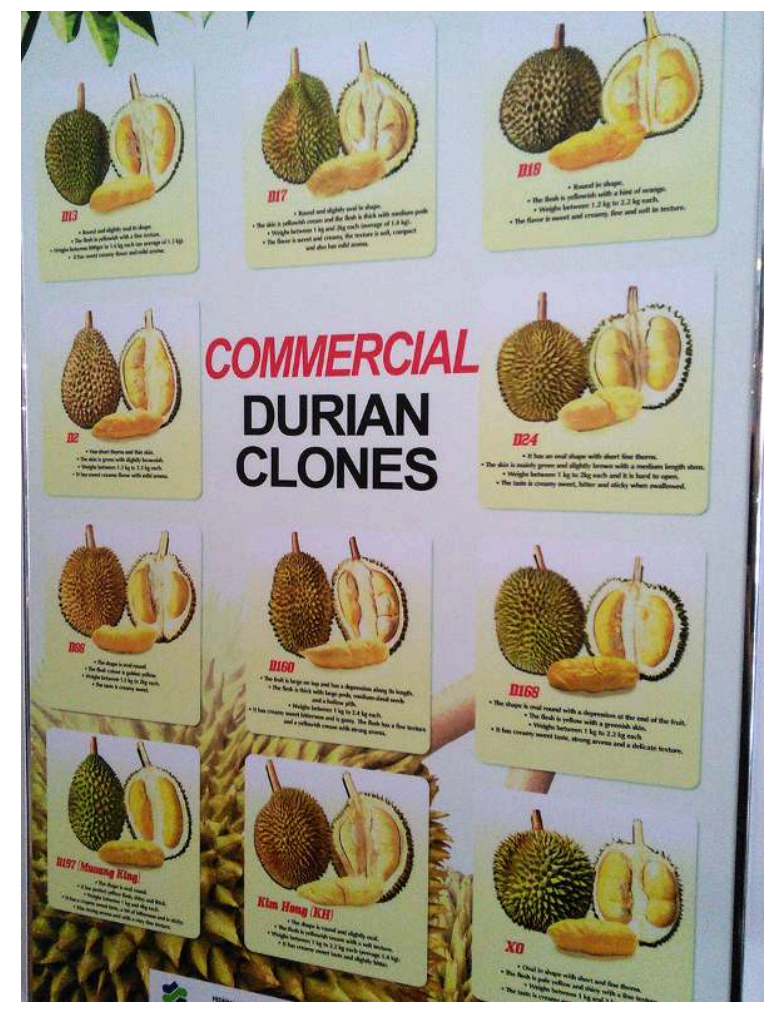

A POSTER WITH BRIEF PRESENTATIONS OF THE PHYSICAL CHARACTERISTICS AND FLAVOR PROfILES OF SOME OF THE MOST POPULAR CULTIVARS PRODUCED IN MALAYSIA

C) L. MARIANI - SINgAPOUR, 2015

Contrary to practices in other regions of Malaysia, the best specimens grown in Penang are not all exported-perhaps on account of the greater distance to Singapore (where most premium quality Malaysian durians are eaten) and the fruit's short senescence process (see infra). But the relative isolation of the local durian production in relation to the durian market that the small city-state naturally constitutes is not solely explained by constraints. While Penang exports only a limited amount of durians, it represents nonetheless an important durian-centered tourist attraction, with visitors flocking here from Singapore, as well as the urban areas of Malaysia, southern China, Taiwan, or Hong Kong (and more recently Western countries). This kind of food tourism, which is the main outlet for the local premium quality crops, exists in other parts of the country as well, but nowhere does it reach the same level. In addition to 
the overall quality of the fruit produced here, the "Penang brand" also plays a part in this success-the island is famous for its beaches, while the capital city, Georgetown, formerly a British East India Company trading post, is listed today as a UNESCO heritage site. Moreover, Penang's food tourism might have also been spurred by the recent boom in regional low-cost flights, which connect Georgetown International Airport to the rest of Asia; another factor could be the proficiency of some local growers in using social networks and thereby benefiting from the support of a large community of enthusiasts and aficionados.

10 In Malaysia (and Singapore), the wait is an integral part to the experience of any durian lover. First, there is the fruit's seasonality which is observed throughout the country, ${ }^{6}$ making it the more desirable since the window of time is quite short. Across Malaysia and Singapore, the durian is considered the "king of fruits," the best of all. For that reason, no one misses the start of the season, while for many inhabitants of the region it constitutes a major event (Figure 4).

Figure 4: Tourists taking photos of themselves in front of a statue representing the durian as "the king of fruits," in the lobby of Singapore International Airport

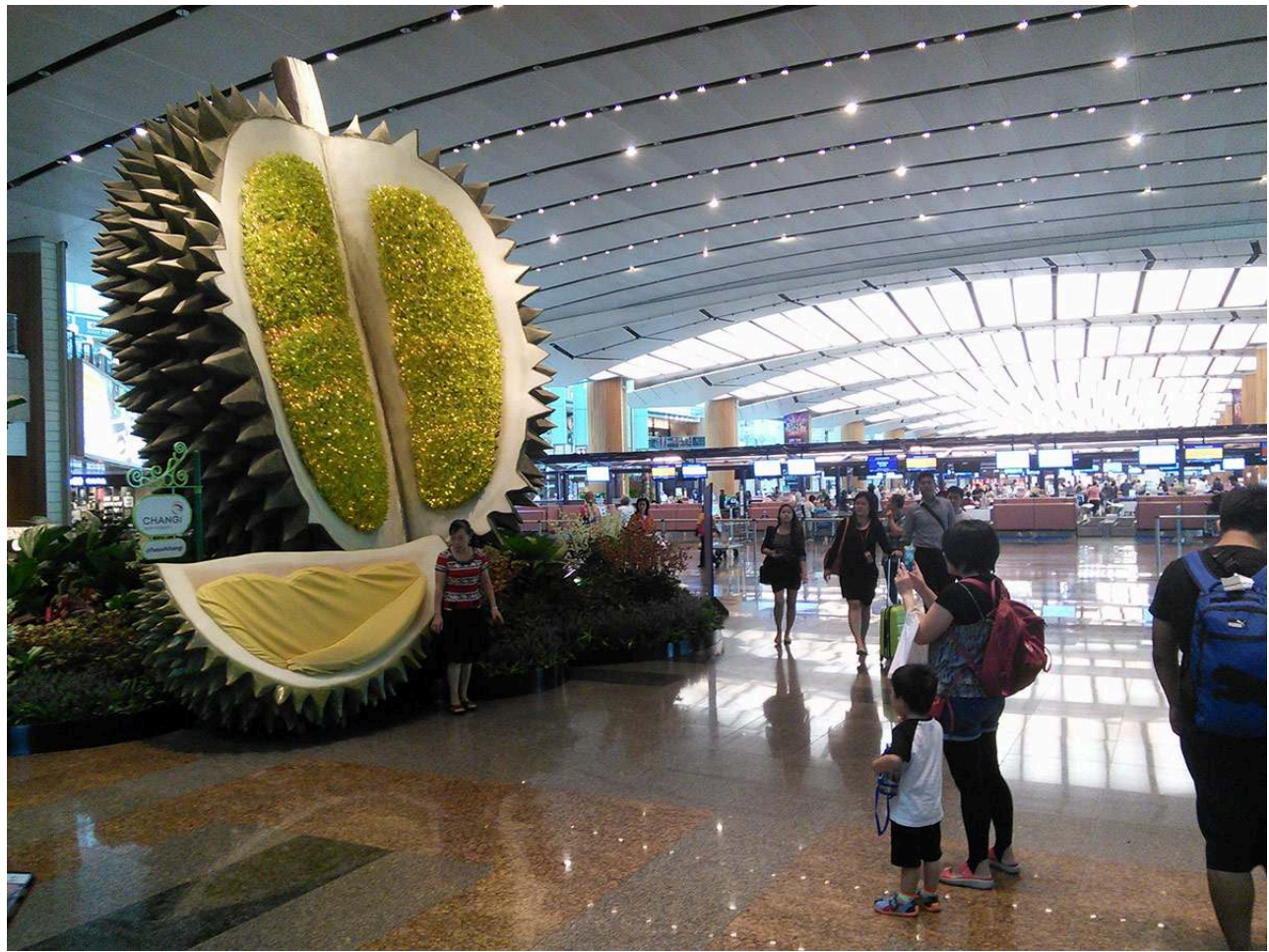

(C) L. MARIANI - SINgAPOUR, 2015

11 But there is yet another constraint that conditions the wait at the height of durian season, with a strong impact on the eating, harvesting, and selling of durians. It is the imperative that the fruit should never be picked from the tree and instead be allowed to fall to the ground on its own. In the next paragraphs, I will elaborate on this imperative because it is essential to understanding the regional market and my argument in this article. One cannot indeed imagine a more radical challenge to the tenets of modern agriculture and produce trade than this principle that hinders the rationalization of production and consumption, while shortening storage time for durians. In Malaysia (and Singapore) however, the market is entirely dependent on it. 
12 According to some accounts I gathered, this constraint is a response to the need to show respect to the tree's "character," which is readily endowed with intentions, as well as an ethics ${ }^{7}$ and a penchant for punishing those impatient enough to cut open its fruits too early by not bearing fruit the following year. The priority they attribute to the tree has concrete practical consequences. It must therefore be interpreted as a fundamental (ontological) configuration of the human-plant relationship, where the latter is likened to a partner with whom the human should come to a compromise rather than a passive object of human designs. Indeed, the durian has, if need be, the means to defend itself: it stops bearing fruit. The majority of Malaysians (and Singaporeans) are very much aware of how singular this orientation is and love to use it to describe themselves and define their identity (see for example Yoon Wah 2013). Thus, the afternoons spent on plantations watching and waiting for the durians to drop are a recurrent motif in Malaysian fiction, arts, and discourses on "Malaysianity." Similarly, the priority attributed to the plant is frequently emphasized when they speak of neighboring Thailand; the Thai also pride themselves on the production of durians, but they always harvest them prematurely there. The removal of fruit from the trees, a practice associated with annual crops and an overall much higher level of industrialization, is characteristic of a mode of production wherein, as opposed to the Malaysian model, humans take priority over plants. ${ }^{8}$ Interestingly, this humancontrolled mode of production is associated with "a taste" for durians which is different from "the Malaysian taste," since the Thais prefer to eat the immature fruit. So, even if the preference for unripe fruit is widespread in Thailand, one is tempted to associate it, in the durian's case, with the technical practices of a type of agriculture that anticipates the maturity of the fruit. One is the more tempted to make this connection since it applies very well to the corresponding Malaysian situation where, parallel to remarks on the character of the tree, people simply claim that they enjoy eating durians when they are perfectly ripe. So, in the Thai case, the durian is both enjoyed and harvested before maturity whereas, in the Malaysian case, it is best eaten ripe and, therefore, conveniently allowed to fall to the ground. In other words, to each taste corresponds an agricultural practice (technique), and, at least in one case, an ontological premise on the hierarchy of life forms. Although an order of causality cannot be established here to identify which one precedes the other-the taste, the practices, or the organization principle-that is, among the three, which one actually "constraints" the others, the association is nonetheless worth remembering, however rudimentary it might be at this stage.

13 Finally, these contrasting practices are indeed remarkably widespread. Thus, visitors can see for themselves that both Malaysians and Singaporeans are of the opinion that durians must fall to the ground and act accordingly. As for the Thai stalls, try as you might and you will not find one durian that was not picked straight from the tree. The constraint that the former impose on themselves is so far not negotiable ${ }^{10}$, at least when it comes to the local production. On the other hand, everybody knows that the Thai durians sold for next to nothing throughout the year have ripened far from the original tree. Even fruit thieves (quite many when it comes to durians) who go "scrumping" on other people's properties observe this rule. In Singapore, where the production of durians is meager but the love for them is all-consuming, people can spend entire nights in public forests hoping to hear the fruits drop, when it would be infinitely easier to simply pick them by hand. On Malaysian plantations, there are employees whose task is to watch the trees and gather the fruits as they fall. To make 
sure that the durians don't tumble down the steep slopes and get ruined in the fall, nets are sometimes placed beneath the branches (Figure 5). For those trees known to yield premium quality fruit, the employees sometimes tie a piece of string around each durian's stalk (and there can be as many as a hundred of them in one tree), they loop it around the fruit-bearing branch, and finally they fasten it to the trunk. When the ripe durian falls, it remains suspended by the stalk until it can be picked by hand.

Figure 5: On the plains of western Penang

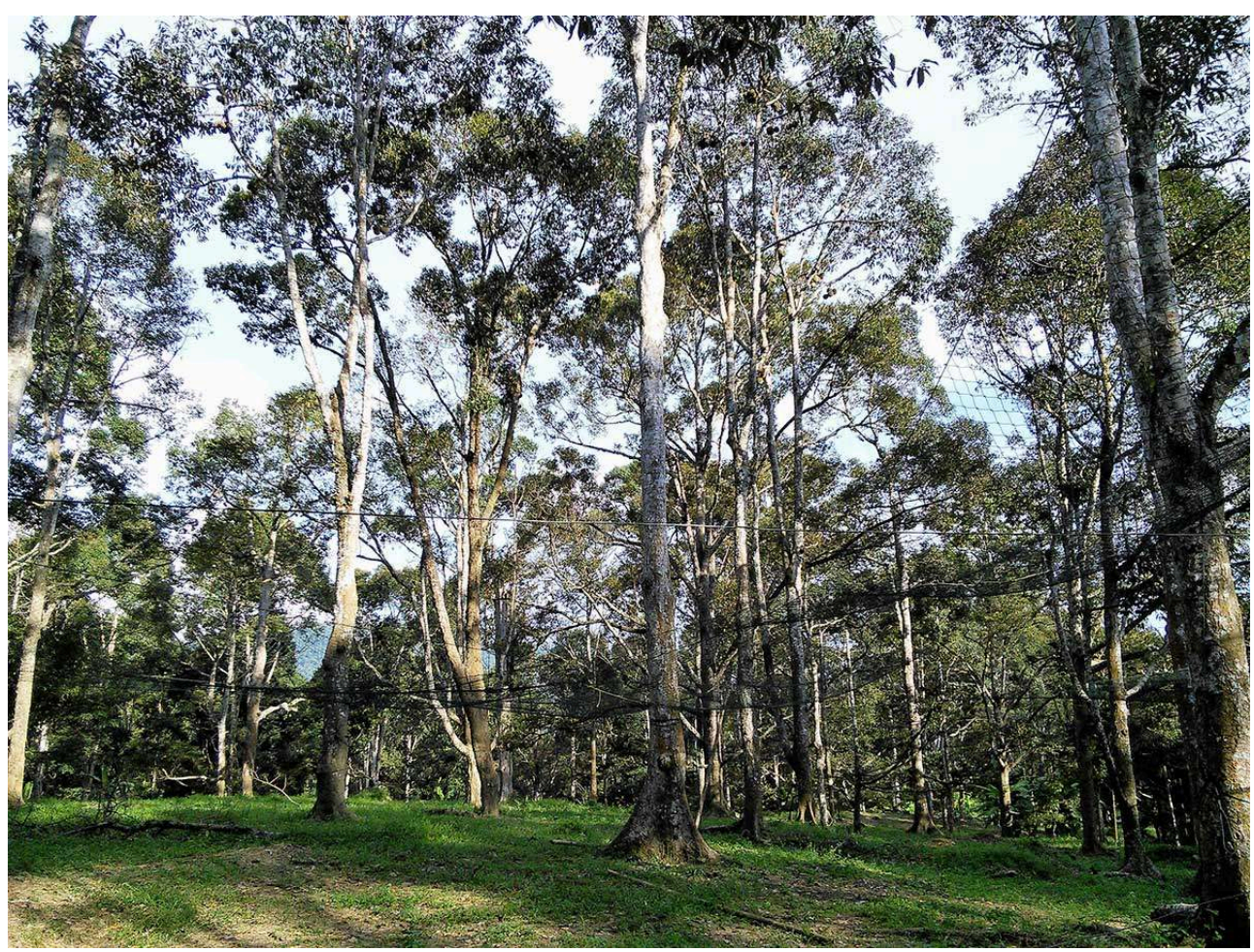

MOST LIKELY OLD TREES (gIVEN THE SIZE), NOT gRAFTED (gRAFTED TREES ARE SMALLER AND SLOWER TO AgE). YOU CAN MAKE OUT THE NETS PLACED UNDER THE BRANCHES TO CATCH THE FRUITS AS THEY FALL

(C) L. Mariani - Penang, 2014

\section{Tasting numbness}

14 Tim receives his guests on a shaded terrace, surrounded by plantations, where his employees keep bringing durians throughout the day. The fruits are often delivered in big baskets, which can weigh as much as a hundred kilograms, carried on the backs of scooters that come and go from dawn till dusk. But the majority of durians arrive in the morning since the fruits tend to drop from the trees at night (Figures 6 et 7). 
Figure 6: Very tall trees (30 meters or more) bearing fruits

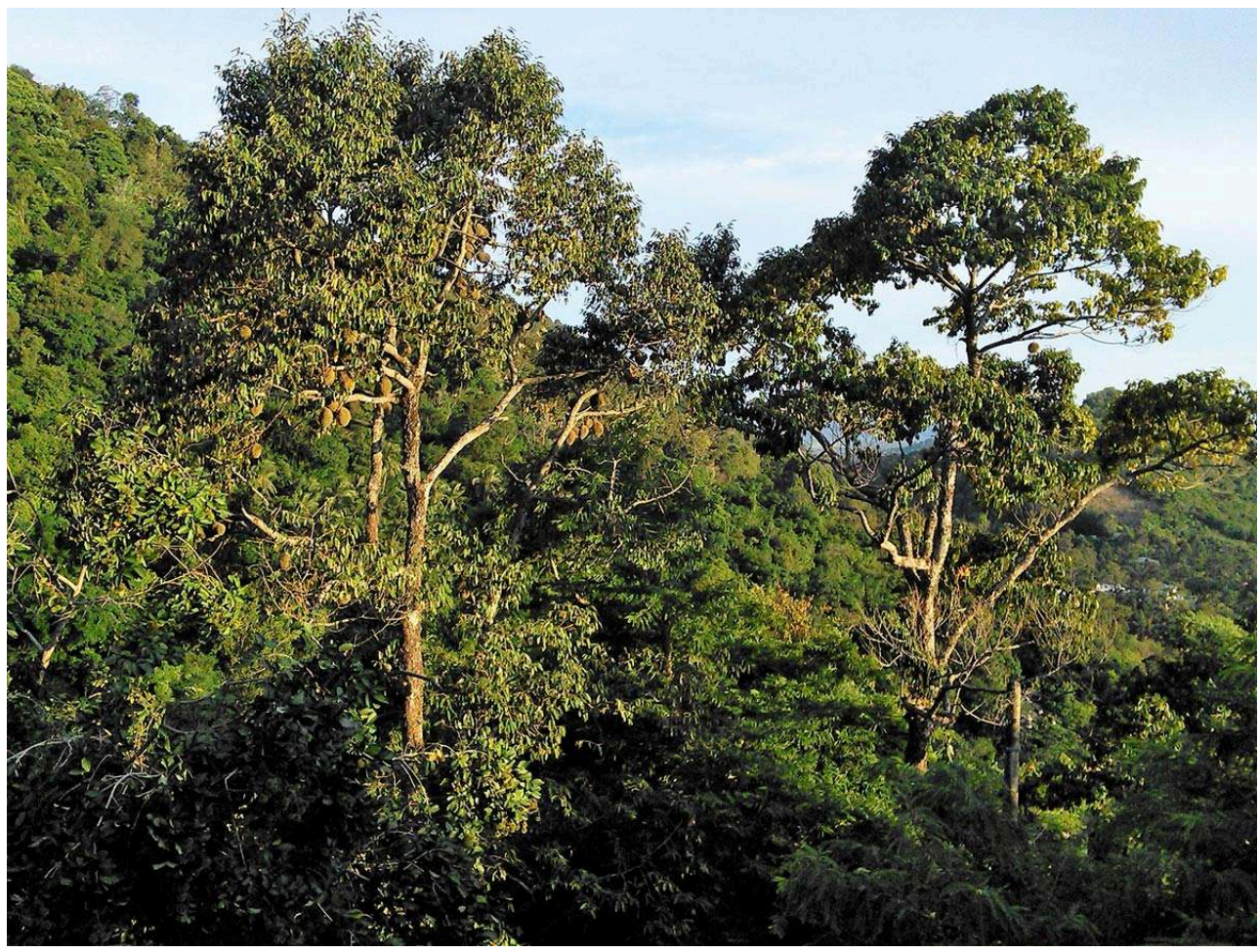

(C) L. MARIANI - PENANg, 2014

Figure 7: Outline of a typical durian tree (grafted, Red Prawn cultivar)

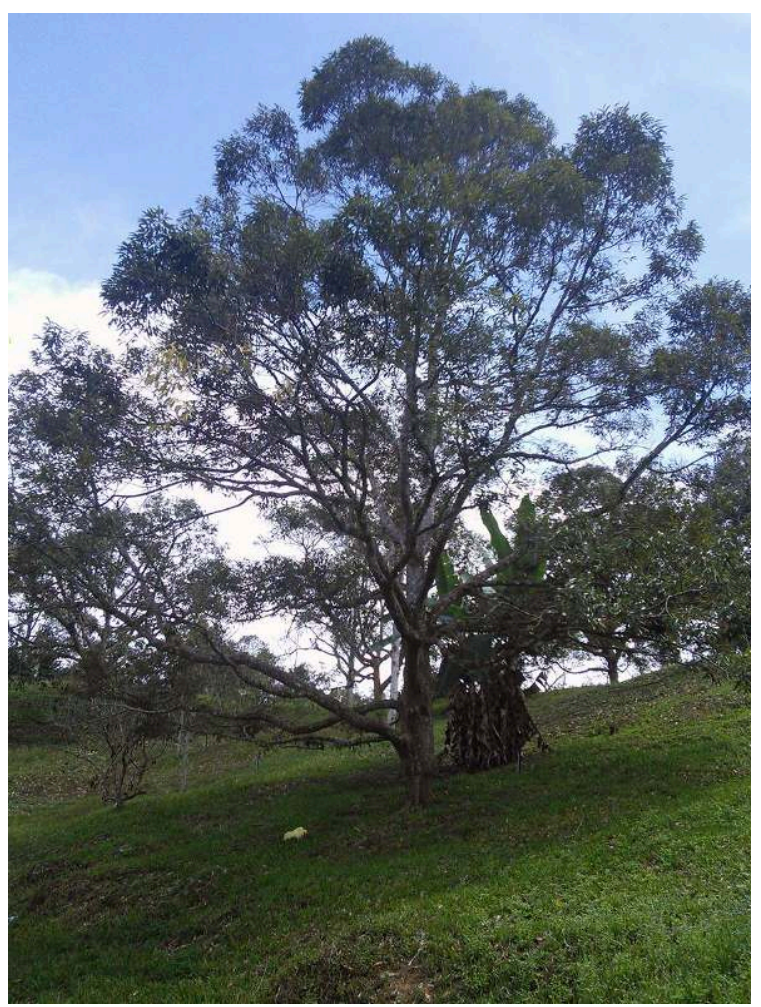

(C) L. MARIANI - PENANg, 2014 

the fruit's freshness. In Singapore and Malaysian large cities, the most prized are samenight durians (or the morning ones if they arrive in the afternoon). For fruit that fell the previous day, as the trucks arrive loaded with new fruit from the plantations, chances are increasingly slimmer to find buyers as evidenced by the low prices at which the fruit left on the stalls go. The freshness requirement appears to be linked to a technical constraint as well since the closer the plantations are, the fresher the fruit is often expected to be ${ }^{11}$ In Tim's case, this is taken to new heights in that he loses almost all interest in the fruits after a few hours (before the urbanites could even have access to them): "they are dead."

To set "the fruit's death" at one time rather than another clearly involves a choice based here on chemical criteria, this choice also offers a glimpse at a pragmatic view of "life as movement" not very different from William James' definition (Latour 2004). In effect, the durian goes through a sequence of rapid, discernable changes in the first hours after it has dropped, before it enters a phase of relative passivity (stability), when its flavors become specified. ${ }^{12}$ According to Tim, the senescence process is triggered by the fruit's hitting the ground. The impact "awakens" the durian, which is why the fruits caught in the nets must be hit on the ground, because they are still "asleep." The period of uncertainty that ensues takes up all of Tim's attention. In this phase, nobody knows "which way the durian will go", whether it will develop the bitterness that some love so much and/or the sweetness that suits the taste of others. ${ }^{13}$ In some cases, the doubt and the confusion are further complicated by the emergence of a completely unique flavor, a taste that many find unsettling, but which is by far the most worthwhile for Tim because, he claims, this taste potentially "contains all the others," namely the numb taste. Since chemists seem to have taken no real interest in it so far, I will explain its occurrence using a hypothesis. A specialist in fruit chemistry suggested me that the release of stress-related ethylene following the shock of the fall could account for this taste. This hormone involved in fruit ripening influences the production of various other chemical compounds, and its high volatility could explain the transiency of the effect. ${ }^{14}$ The fact remains that the paresthetic sensation it induces is rare and elusive in practice. Even if Tim claims that the fruit of old durian trees or particular varieties are more likely to trigger the numb taste, there is however no guarantee.

Every morning throughout the season, Tim waits for the durians that dropped the night before to be brought to him; but he cannot know the exact time they fell. So, before he can offer them up for tasting, he has to group and order them according to the development stage and their potential. Since durians are not cut open before they are eaten ${ }^{15}$, his assessment must be carried out without any direct contact with the flesh protected by the thick, thorny rind. Thus he evaluates them one by one, with the ease and speed of habit, relying on a complex repertoire of clues on which he can draw according to his needs. So, depending on the case, the durians will undergo:

- visual examination (The shape, the distance between the spikes, the color or the consistency of the juice running out of the stalk allow him to estimate the age of the original tree and the fruit's freshness-all this information is checked against the characteristics of the cultivar, if it can be determined.)

- weighing up (to estimate the volume of the seeds and therefore gather some clues on the density of the flesh)

- smelling by touching the nose between the thumb and the index which rest on the

Revue d'ethnoécologie, 14 | 2018 
husk (This allows him to gather general information on the fruit's potential and to identify the numb taste-Tim smells the apex of the fruit because that part matures slower and, according to him, gives him more reliable clues on the maturity of the whole fruit.)

- light shaking (The durian is a fruit with arils, so if you give it a jerk, you can feel them move inside their compartments-depending on how spontaneously and easily they move, one can tell how ripe the fruit is and the quality of the arils; the latter are supposed to move because that means that they have started to come away from the inside of the husk and therefore to become "candied", but not too much because that would indicate over-ripening.)

- tapping with finger nails, a stick or the handle of a knife (The sound that it makes is a good indicator of maturity too-dull means it's too early, hollow means it's just right.)

This is an ongoing process, because Tim must constantly adjust the timing of the fruits to that of the guests; with an eye on the development of the former, he fine tunes their distribution as the guests and new durians arrive. This results in an uninterrupted choreography that revolves around the fruit. The changes that occur deep in the durians are at the heart of the experience that Tim proposes to his guests. He can invite them to follow the development of a still "sleeping" durian, or to forget another one cut open on the table, only to come back to it later. It is all about adjusting to uncertainty and valuing contingency. In other words, Tim engages in a plurality of dialogues with individualized durians as he enters a meaningful, sensory relationship with each fruit, a relationship which is constantly challenged. In this relationship in the making, the attention of the maker is focused on a highly unstable quality: the numb taste, the taste that "contains all possible tastes," unfolding in a moment of pure potential. The taste experience is played out in that which the durian merely suggests, a form which transcends the fruit, as illustrated by an aesthetic principle recurrent in the history of China and its peoples as Sabban (1996) and Jullien (1993) point out.

But the numb taste often unsettles those who experience it, and Tim's customers make no exception to that, used as they are to the pleasure of fully-formed flavors and the less equivocal enjoyment offered by the (relatively) stabilized durians they buy from most Malaysian and Singaporean fruit stalls or even by Tim's durians once they overcome the unsettling numb taste phase. But those fruits "are dead because they don't move anymore," their grower tells us. Tim's taste is not photographic, it does not call up a picture that one could attempt to describe. ${ }^{16}$ It is an eventful taste, a murmuration of potentialities. The taste of the calm before the storm, an evanescent sensation or intuition that one could, for a moment, grasp the potential energy of all becomings. This taste never grows into sapidity. It is instead realized, upstream from any form of determination, in the momentary encounter between taster and tasted, both existing on a spectrum of possibilities. This moment is not given, it must be sought for. In this sense, Tim is very much "like primitive hunters," he "dwells" the taste, because he finds his way "by following a trail rather than by studying a plan" (Leroi-Gourhan qtd by Ingold (2013:26)). From the primitive hunter Tim takes the instinct of the tracker who rejects the prey the moment the tracking is cut short by the capturing. In practice, he tastes very few fruits, or he does it sparingly, as if it were enough for him to capture this moment of bare simplicity when the taste is yet to become taste, the appetite is whetted not so much fulfilled, it remains open. 
In short, Tim does not simply make do with the contingency of the fruits-which would be already a lot-he valorizes it by placing their autonomy, variability, and diversity at the heart of the experience he offers his customers. Behind the numb taste, there are "living" fruits that he shows to his guests, guiding their attention along the trail of the individual fruit without as much as pushing them once, full of precautions and restraint. Finally, the only time Tim initiates the interaction is when he knocks the "sleeping" durians on the ground to wake them up. It should be no surprise then that he never describes himself as a durian "producer," because that would amount to assuming paternity for the fruits, but rather as a "midwife," as if to emphasize his outsider, open position as "welcomer."

\section{Contingencies and universality. The time of fruits or the time of humans}

21 Tim's case is not representative, but it has the advantage of bringing into relief the foundations of the relationship between humans and durians as it is found across Malaysia and Singapore. As shown, this relationship is a fundamentally contingent one since it is conditioned by the fall of the fruit, or better of "each fruit," because, in this configuration, each durian requires its own moment of attention. Humans can at best estimate the time of the fall, but they cannot predict it. Nor can they know the exact amount of fruit that tomorrow will bring or the cultivar or tree that will yield it.

By letting the durian take the initiative, Malaysian growers go against economic good sense. They complicate stock management and considerably limit the outlets available to their crops, because a durian that comes off the tree is much more fragile and perishable than one picked by hand ten days before it ripens. Transporting it is riskier too because the fruit is dangerously close to the fateful moment when it will go bad. This explains why Malaysian durians are not habitually exported beyond Singapore and why, in this part of Southeast Asia, the chain formed of humans and durians knows no idle time: from gathering to eating them, it is a case of just-in-time production. The durian touching the ground starts a race against the clock, which sweeps everything in its wake. The fruits must be gathered, sorted, and delivered in the shortest time to the points of sale. At dawn, Singapore sellers get in touch with their suppliers. They estimate the time of arrival of the trucks, take note of the shipment details, and prices. Almost simultaneously, the information is shared on social media: the phones start ringing, the orders start pouring in, and the Singaporean workers plan their breaks or route after work. During the few months of the durian season, each day goes the same: the durian imposes its conditions. For the best fruit, it will take under twelve hours between the time of the fall (sometimes eight hours away from Singapore) and the time of eating. Subpar durians will be later sold at a discount or even processed, sometimes cooked, but only as a last resort, to waste as little as possible.

Tim's relationship with his fruits provides a condensed version of the chain above, especially in terms of temporality and spatialization. In part, this difference in configuration is attributable to the producer: his durians are "alive" for only a few hours (a restriction related to the numb taste). This highly ephemeral edibility exacerbates their influence on the overall organization and the spatialization, tying them down to their place of production. In absolute terms, there is no reason why these durians should not be consumed elsewhere. They could easily be transported to 
Singapore along with many others. But then they would become ordinary fruits, not "those durians" that become defined in relation to Tim, at his house. "Those durians" exist only there, shaped by the inextricable contingencies that make them what they are and, at the same time, enable the way we can experience them. ${ }^{17}$ In this entanglement, which would be better described as concrescence, Tim is a passeur or montreur, ${ }^{18}$ as the whole remains subordinated to the fruit. In its fall, the durian draws out people's inventiveness, forcing them to adapt. Ultimately, the durian is the one which attracts the curious crowds, making them travel thousands of kilometers to experience what it has to offer only under the exact circumstances of its place of origin. Earlier, when I attributed all the credit for the success of food tourism in Penang to the people's discourse, their creativity and marketing strategies, I let myself be carried away by a rather common anthropocentrism. It would be fair now to give to the fruit what is indisputably the fruit's, something that all Malaysians agree with and live according to: the privilege of initiative. In passing, the entire durian trade of the island could be reinterpreted as an adaptation (a valorization) of the priority people give to the tree in this relationship. This is not to say that the man-made and environmental conditions of Penang did not concur to the development of a durian-centered tourism. But the fact remains that the tourists had to travel to the durians because the fruit could not travel to them. These fruits, valued for the unique connections that they have always carried, are without a doubt the best advocates of the island's production. After all, they make the gourmets of Singapore-however well stocked they might be-dream and fly in for a weekend.

The priority granted to the tree throughout Malaysia informs all of the practices that I could observe while there. The examples I introduced and discussed show that this priority induces a kind of diffuse tropism; the fruit's temporality leaves a mark on human worlds in the form of "a slope" or a curve. On Tim's plantations and on the stalls of Singapore, the time of the fruit conditions everything, from the technical and spatial practices to sociabilities and working hours. Tension varies in intensity across the spectrum, with the curvature-think of spacetime representations from the theory of relativity-becoming more pronounced the closer we are to the place of production. Keeping this image in mind, Tim stands where the warp in the spacetime is deepest, in the proximity of a star (a durian). Penang Island is just above that point, on the next level, and from it the lines of the network spread all the way to Singapore. For now, the spacetime of Malaysian durians does not go any farther than that, because available means don't allow it. It remains in its entirety centripetally oriented towards the places of production (or the fruits). ${ }^{19}$ Only the fruits' fame reaches beyond the borders of the country, so that the Sultan of Brunei himself makes occasional trips (using his personal jet) to Singapore to sample the fresh durians-although he lives on an island known for its durian crops.

Let us now go back to the opposition with the Thai case, which Malaysians and Singaporeans invoke whenever they want to emphasize their uniqueness. In Thailand, just like elsewhere, there is a variety of uses and practices surrounding the durian, but they all have in common the fact that they cut the fruits open before they are ripe. From the outset, the fruit's temporality is subordinated to human temporality, which necessarily influences the overall possible relationships between the two. I will not try to formulate here the deep motivations of this gesture, but I will describe its benefits and drawbacks. For one, there are the obvious advantages of having a supply in storage: “[a] playing field (...) for mass treatment" (Guille-Escuret 2018:91). The moment the 
fruits stop setting themselves the time of eating, humans start making all the decisions. They can then decide to pick the durians in advance and to preserve them in cold stores, for example. They can then export the fruits to the other end of the world,$^{20}$ or even to Malaysia and Singapore, selling at lower prices than the local production, which they anyway replace during the eight months outside the season. Cutting the durians is also a sine qua non condition for developing a type of agriculture that seeks to rationalize processes and costs, as perfectly illustrated by industrial agriculture. Many Thai farmers understood that and developed high-yield annual crops, thus obtaining large quantities of fruit at the expense of exhausting the trees. At present, this type of farming is organized around three high-yield varieties-in a country that has 300 officially recorded cultivars-whose agricultural behavior is controlled from start to end, regulated by rationalized processes that measure out the time of production in days and use mechanized pollination, handling, and picking (Figure 8).

Figure 8: A durian hanging by the stalk from a branch

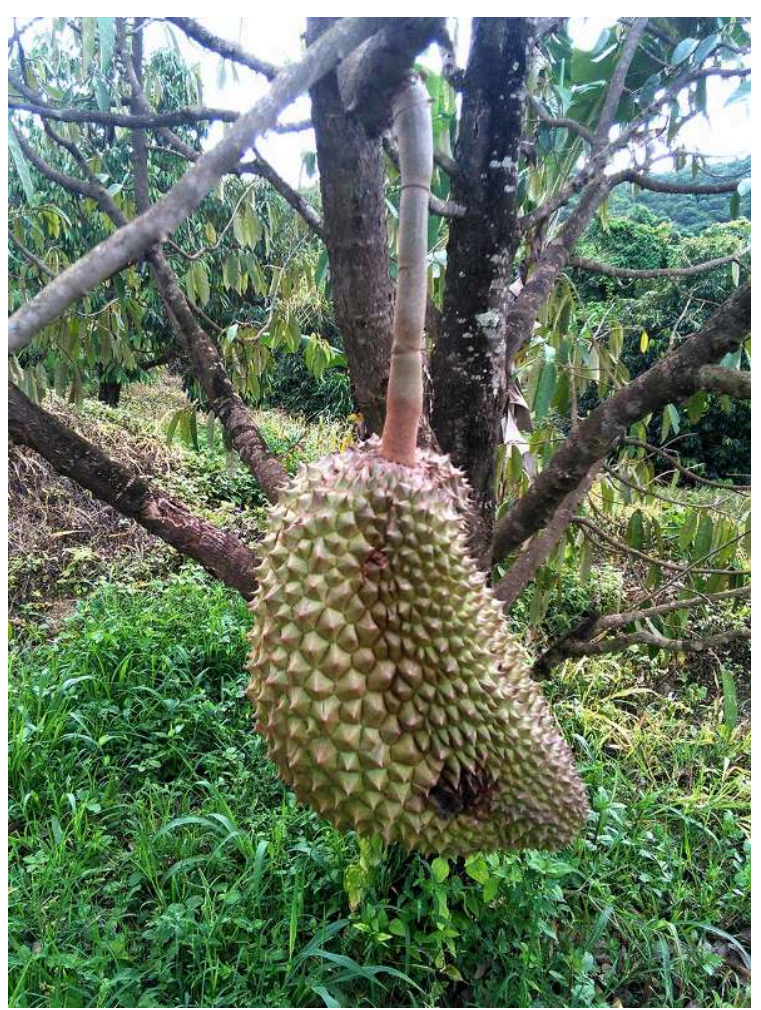

Despite the unusual shape, the fruit belongs to a very common, high-yield Thai variety (Monthong). It is grown extensively today in Thailand, Cambodia, and Vietnam, as well as Indonesia (but verry little in Malaysia)

(c) L. MARIANI - CAMBODgE, 2014

This is man-made agriculture through and through; it stabilizes and subordinates the agricultural behavior of plants (Bonneuil \& Thomas 2010) to imperatives of its own making. It certainly has its advantages because, for instance, it can guarantee an average, standardized quality of fruits, as well as regular income. By restricting the effects of contingency, the dependence of the plants on the place and the grower, it crushes however their qualities, particularly their specific temporality, under the weight of the qualities humans attribute to them. Under these circumstances, it stands to reason that Tim's taste simply cannot occur here. Similarly, stabilizing and 
standardizing the way the fruits are grown is going to induce a corresponding stabilization and standardization of tastes since one of the main qualities of the fruit thus produced is to guarantee stable organoleptic qualities. Therefore, it becomes apparent that the existential relation manifested in the taste is duplicated in the way the environment is managed.

Thailand and Malaysia stand on opposite sides of a ridge line. Although I'm sure the practices in the two countries do meet in some cases, the slope is steep on either side. Giving priority to the tree or the human is not without consequences; each choice begets different opportunities, both agricultural and existential. The world is full of projects aimed at valorizing the diversity of local production: whether it's potatoes or corn in South America or cheese and wine elsewhere. The underlying intentions are always good. But to stabilize diversity in order to save it poses a problem, or at least raises a question. It is in fact seldom that human groups who produce diversity do it for the sake of producing diversity. To stimulate them to do that might very well distract them from their genuine preoccupations, from what they define as worthwhile for them: the satisfaction in a taste, their needs, sociabilities, ideas, or even simply curiosity. It goes from here that perhaps the solutions to the deflation in biodiversity observable all around us are to be found elsewhere than in the management of biodiversity. In other words, was General de Gaulle right to claim that France is ungovernable because it makes so many types of cheese? Or is it the other way around: being ungovernable enabled France to diversify its production of cheese, as GuilleEscuret claimed (1988:23)? This question is as topical as ever. In Malaysia, the creation, exchange and diffusion of new durian varieties still outpaces by far stabilization and standardization processes-even though certain successful cultivars tend to dominate the market. To these dozens of cultivars, wild, spontaneous creations are added, born out of cross-pollination and "natural" dissemination. For now, there is however no legal framework or even national plan in place to regulate this diversity, which remains the result of an interested yet open collaboration between humans and trees.

\section{Conclusion}

28 A few decades back, a French author whose work has yet to be translated into English (Haudricourt 1962) devised a set of oppositions which are echoed in this article. First, he distinguished between two approaches to plants: one that proceeds by indirect negative action and another one that uses positive direct action. Next, he defined two archetypes to account for the range of contrasts: a "Near Eastern" model, characterized by the use of grain, direct contact, a prescriptive attitude and selective pressure (increased control over plant propagation); and an "Oceanian" model, where people favored an indirect relationship with the tubers, negative support (protection through working the soil around the cuttings) and a collector's curiosity (accumulation of clone plants with different characters). Further, he claimed that the opposition between the two modes of action was replicated in all types of relations, especially those between humans; but I will not dwell on this last point here. Nonetheless, there are visible similarities between Haudricourt's theory and my research. Taking the comparison even further, I must add that each mode of production informs existential perspectives (see also Mariani 2018). The selection and stabilization of fruit varieties that look the same everywhere does not only impact the world. The consumers themselves are 
affected if only because, sure to find what they expect (and only rarely disappointed), they no longer need to renew their engagement with the food, smelling or touching them every time in order to know them. At the other end of the spectrum, contingent foods, with Tim's durians being their flagship, are inciters. They push their luck every time: one has to try them to see what they are all about. On the one hand, there are fruits that replicate the characteristics of the class or category they belong to, with each fruit being an embodiment of the category, and by this they are abstract; and, on the other, there are fruits that constantly challenge the category they belong to, they are contingent. The former can be easily consumed for what they are, as guaranteed by the stabilization processes that they undergo in the first place, and therefore tend to engage the cognition. Whereas the latter make us experience what they are capable of, and for this reason they will engage primarily the senses.

Tim's passion for the fruits and collector's curiosity have the advantage of enriching both biodiversity and knowledge about the lifeworld. On the other hand, they are costly, not democratic, and hyperlocalized, which raises some environmental concerns of its own (since people fly here for the experience). The durians grown on Thai industrial plantations are not any less problematic in environmental terms, but they can be tasted by everybody, everywhere. They do not engender privilege. But they don't provide any original experiences or knowledge of the world either. They don't teach us that the taste for a strange tingling sensation can change lives, as well as the face of a place and the networks associated with it. The former, whose value is contingent, exercise attraction because they trigger a rare desire, often with disappointing results, while the latter are caught in a centrifugal movement of expansion that takes them closer to universality, i.e., the possible satisfaction of an ever greater number of desires. Let us remember that Tim's taste had more to do with whetting the appetite than with actually satisfying it. Curiosity for things or satisfaction of desires, interspecies companionship or domestication, humans seem to constantly waver between taking up all the space and sharing it with non-humans. In any case, they have the choice, and in this choice their bodily commitment and their humanity are played out.

\section{BIBLIOGRAPHY}

Bonneuil C. \& Thomas F. 2010 - Purifying landscapes: The Vichy Regime and the Genetic Modernization of France. Historical Studies in Natural Sciences 40 (4) : 532-568.

Guille-Escuret G. 1988 - La Souche, la cuve et la bouteille. Les rencontres de l'histoire et de la nature dans un aliment : le vin. Paris, Éditions de la Maison des Sciences de l'Homme, 197 p.

Guille-Escuret G. 2018 - Social structures and Natural Systems. Is a scientific Assemblage scientifique workable?. Londres, ISTE editions, $240 \mathrm{p}$. 
Hagura N., Barber H. \& Haggard P. 2013 - Food vibrations: Asian spice sets lips trembling. Proceedings of the Royal Society B 280 (1770). [En ligne] URL : http:// rspb.royalsocietypublishing.org/content/280/1770/20131680 Consulté le 24 novembre 2018.

Haudricourt A.-G. 1962 - Domestication des animaux, culture des plantes et traitement d'autrui. L'Homme 2 (1) : 40-50.

Haudricourt A.-G. \& Dibie P. 1987 - Les pieds sur terre. Paris, A.M. Métailié, 197 p.

Hennion A. 2007 - Those things that hold us together: taste and sociology. Cultural Sociology 1 : 97-114.

Ingold T. 2013 - Lines. A Brief History. London-New York, Routledge, 186 p.

Jullien F. 2004 - In Praise of Blandness: Proceeding from Chinese Thought and Aesthetic. New York, Zone Books, 176 p.

Latour B. 2004 - How to Talk About the Body? The Normative Dimension of Science Studies. Body \& Society $10(2-3): 205-29$.

Lévi-Strauss C. 1964 - Mythologiques, t.1 : Le Cru et le cuit. Paris, Plon, 403 p.

Mariani L. 2015 - L'Exotisme et le fruit de l'imagination : le-durian-qui-partage-l'humanité-endeux. Anthropologie et Sociétés 39 (1-2) : 313-328.

Mariani L. 2017 - Une odeur d'enfer. À propos du devenir universel des qualités organoleptiques d'un fruit. Techniques \& Culture $62: 48-67$.

Mariani L. 2018 - Matières à manger. Propositions pour penser les rapports humains/aliments. Revue d'Anthropologie des Connaissances 12 (3) : 429-453.

Mintz S. 1996 - Tasting food, tasting Freedom: excursions into eating, culture and the past. Boston, Beacon, $149 \mathrm{p}$.

Pareyson L. 2007 - Esthétique : Théorie de la formativité. Paris, Édition Rue d'Ulm, 352 p. [En ligne] URL : https://books.openedition.org/editionsulm/959 Consulté le 24 novembre 2018.

Sabban F. 1996 - Art et culture contre science et technique. Les enjeux culturels et identitaires de la gastronomie chinoise face à l'Occident. L'Homme 36 (137) : 163-193.

Van de Port M. \& Mol A. 2015 - Chupar Frutas in Salvador da Bahia: a case of practice-specific alterities. Journal of the Royal Anthropological Institute 21 (1) : 165-180.

Yoon Wah W. 2013 - Durians Are Not the Only Fruit. Notes From the Tropics. Singapour, Epigram books, $175 \mathrm{p}$.

\section{NOTES}

1. This article is based on several stays in Malaysia and Singapore, from 2014 and 2018 (six months in total). Throughout it, the two countries will be often mentioned together. As far as the durian and the durian trade are concerned, the countries form a unit, not least because Singapore absorbs a large part of the Malaysian output. More than that, the two countries share a history, given that they only became independent from each other in 1965 . The compositions of their populations are also similar, even if the ethnic percentages are divergent-a legacy of colonialism, the populations of Singapore and Malaysia are mainly composed of Chinese, Indians, and Malays.

2. I thank Simon Gérard for pointing me to this book. 
3. Just like there are famous grape varieties (and famous varietal wines), there are also durian varieties with a good reputation. Some of them are old (D1 and D2 were the first Malaysian varieties to be officially recorded in 1934), others are only a few years old (the latest were recorded in 2017). For example, Penang's iconic variety the Red Prawn (Udang merah in Malay, Hang hae for Chinese speakers) dates from long before 1990 when it was officially recorded, whereas Black Thorns (Duri hitam in Malay, Ochee for Chinese speakers) is a more recent variety (2012) which has proven also very successful. It should be mentioned that there are more durian varieties grown in Malaysia that the roughly 200 official entries in the government's registers. In fact, many "inventors" do not go through the registration procedure.

4. The resulting limited diversity of cultivars is relative, especially compared with other crops. Successful pollination requires that a durian plantation include at least four or five different cultigens. Since the flowers are hermaphroditic, the pistils and the stamens are not fertile simultaneously, which makes it safer to rely on an extended flowering period. The main pollinators are bats, birds, and bees. However, the success of particular varieties, such as the D197 cultivar (Musang King, Raja Kunyit or Maosang wang), over the past twenty years has stimulated growers to adapt their crops to the demand (grafting popular cultivars on existing trees because planting new ones would take more time).

5. Knowing that the flesh constitutes about a third of the overall weight of the fruit, this gives an idea of how expensive some durians can be (Malaysian durians weigh on average $1.5 \mathrm{~kg}$ ).

6. Caught between the Andaman Sea and the South China Sea, which have very different temperatures, mainland Malaysia faces two monsoon seasons. The durian harvest can therefore be divided among three areas. In Penang, it reaches the peak between June and July. A little farther down on the west coast all the way to Singapore (where they are only sporadically grown), the season arrives about a month later. Finally, in the east and the central highlands, the season starts in July and ends in September. In all three areas, the trees bear fruit twice a year, but the second harvest, around December-January, is smaller. Thanks to continuous imports from all these areas, Singapore is undoubtedly the place where you can eat Malaysian durians for the longest time.

7. The tree is believed not to let its fruit fall on the heads of good people, especially those of children who often cross the plantations, on their way to school for example.

8. I will come back to this point later, but it stands to reason that this fits much better with the principles of capitalist economic good sense.

9. The opposition of tastes here is not to be taken literally as it does not imply that the taste is not the same in both cases. It echoes instead a principle (ripe vs. unripe) which is common to all tastes.

10. Indeed, even the research programs implemented by the Malaysian government are conditioned by this cultural choice, as most of them integrate the need to develop improved methods of preservation that would enable them to export the fruits after they have fallen and to preserve the flavors (which are altered by freezing or keeping them in cold storage).

11. Or they are sold to novices who lack the necessary knowledge to discuss quality.

12. In this phase, the fruit's development does not stop altogether, but it slows down considerably.

13. Bitterness, sweetness and bitter-sweetness are the main criteria for choosing fruit on the stalls; the variety also matters since some cultivars are known to develop one taste more than another. Durians come in an infinitely wider range of flavors, but people often show no interest in defining them.

14. I want to thank Michel Génard for these cautious suggestions, and I take full responsibility for using them.

15. Malaysian and Singaporean stalls sometimes sell pre-packed durian flesh. This treatment is reserved to poor quality durians and target customers who are less demanding and/or not 
affluent. This is yet another significant difference between Malaysian and Thai practices, since in Thailand the fruit is often pre-packed regardless of its quality. Another Thai practice is to cut a small "window" into the husk of the fruit, which can be opened to peek at the flesh and then sealed back if it is not ripe enough.

16. To his Western customers accustomed with the flourished discourse of wine tasting, Tim's descriptions of the fruit's flavors sound very sparing.

17. Apart from these contingencies, there are Tim's agricultural practices, the old age of his trees, in short the collective conditions that make it possible for durians to exist the way they are, in this particular place only.

18. In French, a passeur is, among others, the ferryman; Tim carries his guests from one side of the taste to the other, guiding them without intervening; he is also a montreur, the one who points, not dissimilar to the figure that stands to the side and points his finger at the important elements in medieval representations. (Translator's Note).

19. I should mention here that durians are successfully grown in the Johor Baru region, on the border with Singapore -where the majority of the investors behind the expansion of these plantations live. Since they don't always have the time and money to go to the fruits, Singaporeans have the fruits come to them.

20. Almost all of the durians which can be bought in the Asian shops of Europe are imported from Thailand.

\section{ABSTRACTS}

Using as a privileged entry point the numb taste - a tingly numbness of the mucous membranes of the mouth, triggered here by a fruit, the durian-this article puts forth an approach to humanfood relations encompassing different modes of knowledge, consumption, and production.

Steering clear of any theoretical abuse, the approach draws on a detailed ethnographical analysis of this particular taste and the general economy in which it is inscribed, between Malaysia and Singapore, to finally conceptualize various ways of producing and experiencing foods and worlds. The emergence of the numb taste will notably be linked to an agricultural and ontological constraint that the producers and consumers from both countries impose on themselves: against apparent economic good sense, instead of picking them, they wait for the durians to fall from the tree.

\section{INDEX}

Keywords: taste, numb taste, affects, techniques, crop growing, temporalities, durian, Malaysia

\section{AUTHOR}

\section{LEO MARIANI}

ATER Laboratoire d'Écoanthropologie et d'Ethnobiologie (UMR 7206) Muséum national d'Histoire naturelle, Paris - leo.mariani@mnhn.fr 